\title{
HUMOUR-ORIENTED CLASSES: CRUCIAL ISSUES
}

\author{
N. O. Leishnova, L. V. Pavlova, O. A. Serheieva \\ V. N. Karazin Kharkiv National University \\ 4 Svobody Sq., Kharkiv, Ukraine, 61022 \\ n.o.leshnyova@karazin.ua, https://orcid.org/0000-0002-5363-976X \\ I.v.pavlova@karazin.ua, https://orcid.org/0000-0002-5854-4209 \\ o.a.sergeyeva@karazin.ua, https://orcid.org/0000-0002-1118-8403
}

\begin{abstract}
In the article presented humor has been considered as an integrant part of foreign language teaching that can facilitate more effective students' learning. The purpose of this study is to identify the role of humor in teaching foreign languages at non-linguistic faculties in the conditions of shortening classroom hours and the most appropriate types of humor to use in a classroom for the successful acquisition of a foreign language by university students. To deal with the tasks and achieve the research purpose, theoretical and qualitative research methods have been used: the analysis of pedagogical and psychological works, the systematization of scientists' views and achievements combined with many years of teaching experience and observations. It has been noted that humor can take many forms and perform a variety of psychological functions in modern society. At university humor helps to learn in two ways: right through the emotional sphere and stimulating the process of cognition and indirectly by means of creating a more welcoming atmosphere, which in turn has a positive impact on the success of knowledge acquisition. Humor has a powerful effect on mental activity and consequently, improving the capacity of involuntary memorization, causes a kind of reflexive orientation to novelty. Moreover, humor is an express method of psychological relaxation in class. Special attention has been paid to the impact of humor on the emotional state of students and finding the most appropriate types and forms of humor to be used in class. An attempt to prove the importance of using humor in class in order to improve students' acquisition of a foreign language in a higher education institution, notwithstanding the shortening of classroom hours according to the language course has been made.
\end{abstract}

Key words: foreign language teaching, humor, types of humor, emotional stimulation, motivation, stress relief

Н. О. Лєшньова, Л. В. Павлова, О. А. Сергеєва

Харківський національний університет імені В.Н. Каразіна

майдан Свободи 4, Харків, Україна, 61022

\section{ЗАНЯТТЯ ОРІЄНТОВАНІ НА ВИКОРИСТАННЯ ГУМОРУ: ВАЖЛИВІ ПИТАННЯ}

У представленій статті гумор розглядається як невід'ємна частина викладання іноземної мови, що сприяє більш ефективному навчанню студентів. Метою даного дослідження є визначення ролі гумору в викладанні іноземних мов на немовних факультетах в умовах скорочення навчальних годин і розгляд найбільш прийнятних типів гумору для використання в аудиторії для успішного засвоєння студентами іноземної мови. Для вирішення поставлених завдань і досягнення мети дослідження були використані теоретичні та якісні методи дослідження: аналіз педагогічних і психологічних робіт, систематизація поглядів і здобутків вчених в поєднанні з багаторічним досвідом викладання і спостережень. Було відзначено, що гумор може приймати різні форми і виконувати різні психологічні функції в сучасному суспільстві. В університеті гумор допомагає навчанню двома засобами: безпосередньо, через емоційну сферу і стимуляцію процесу пізнання, і опосередковано, шляхом створення більш гостинної атмосфери, яка, в свою чергу, допомагає успішно отримувати знання. Гумор потужно впливає на розумову діяльність і, отже, покращуючи здатність до мимовільного запам'ятовування, викликає свого роду рефлексивну орієнтацію на новизну. Більш того, гумор - це експрес метод психологічної релаксації на заняттях. Особливу увагу було приділено впливу гумору на емоційний стан учнів і пошуку найбільш придатних типів і форм гумору для використання в аудиторії. Зроблено спробу довести важливість використання гумору в аудиторії для поліпшення оволодіння іноземною мовою у вищому навчальному закладі, незважаючи на скорочення аудиторних годин.

Ключові слова: викладання іноземної мови, гумор, види гумору, емоційне стимулювання, мотивація, зняття стресу.

(c) N. O. Leishnova, L. V. Pavlova, O. A. Serheieva, 2020 


\section{Н. А. Лешнева, Л. В. Павлова, Е. А. Сергеева}

Харьковский национальный университет имени В. Н. Каразина

площадь Свободы 4, Харьков, Украина, 61022

\section{ЗАНЯТИЯ ОРИЕНТИРОВАННЫЕ НА ИСПОЛЬЗОВАНИЕ ЮМОРА: ВАЖНЫЕ ВОПРОСЫ}

В представленной статье юмор, который способствует более эффективному обучению студентов, рассматривается как неотъемлемая часть преподавания иностранного языка. Целью данного исследования является определение роли юмора в преподавании иностранных языков на неязыковых факультетах в условиях сокращения учебных часов и рассмотрение наиболее подходящих типов юмора для использования в аудитории для успешного освоения студентами иностранного языка. Для решения поставленных задач и достижения цели исследования были использованы теоретические и качественные методы исследования: анализ педагогических и психологических работ, систематизация взглядов и достижений учёных в сочетании с многолетним опытом преподавания и наблюдений. Было отмечено, что юмор может принимать различные формы и выполнять различные психологические функции в современном обществе. В университете юмор помогает обучению двумя способами: напрямую, через эмоциональную сферу и стимуляцию процесса познания, и косвенно, путём создания более гостеприимной атмосферы, которая, в свою очередь, способствует успешному приобретению знаний. Юмор оказывает мощное влияние на умственную деятельность и, следовательно, улучшая способность к непроизвольному запоминанию, вызывает своего рода рефлексивную ориентацию на новизну. Более того, юмор - это экспресс метод психологической релаксации на занятиях. Особое внимание было уделено влиянию юмора на эмоциональное состояние учащихся и поиску наиболее подходящих типов и форм юмора для использования в аудитории. Предпринята попытка доказать важность использования юмора в аудитории для улучшения овладения иностранным языком в высшем учебном заведении, несмотря на сокращение аудиторных часов.

Ключевые слова: преподавание иностранного языка, юмор, виды юмора, эмоциональное стимулирование, мотивация, снятие стресса

Introduction. At present the specialists who deal with various aspects of science and engineering are supposed to be capable of using foreign languages to find the data they need as well as for communicating and exchanging information with their foreign colleagues. Therefore, the second language proficiency level must be high enough to serve these purposes. However, teaching foreign languages to university students is limited to 30 classroom hours a semester or less and only lasts for about two years according to the curriculum. Hence, high school teachers strive to intensify the process of learning and let their students acquire deeper knowledge of the subject. The issue of motivation becomes essential to master the second language better. Using humor for teaching foreign languages is one of the effective means to stimulate students' motivation.

Analysis of recent research and publications. Humor, its different types, as well as its role in teaching foreign language have been studied in numerous scientific works of domestic and foreign authors (McMorris R., Gorham J., Norrick N. R., Martin P., Oppliger P.A. J. Hackathorn, A. M. Garczynski, K. Blankmeyer, Wagner M., Kolesnik G., Prokofiev G., Vasilevskaya O. and others). Nevertheless, there is still a need for a more detailed analysis of the feasibility of using humor in class in the conditions of shortening classroom hours at non-linguistic faculties.
Objective. The purpose of this study is to identify the role of humor in teaching foreign languages at non-linguistic faculties in the conditions of shortening classroom hours and consider the most appropriate types of humor to use in a classroom for the successful acquisition of a foreign language by university students.

Methods. To solve the assigned tasks and achieve the research purpose, theoretical and qualitative research methods have been used: the analysis of pedagogical and psychological works, the systematization of scientists' views and achievements combined with many years of teaching experience and observations to develop methodological principles of teaching foreign languages at university.

Results. Humor and laughter are a universal aspect of human life that takes place in all its spheres and is inherent to literally every person [8]. Humor can take many forms and perform a variety of psychological functions in modern society. Among peers, humor helps to attract attention; in the work process by means of humor, in the acts of communication that occur in the group, humor increases cohesion, defines social boundaries, and softens critical statements; in the classroom, students often use humor in order to achieve a friendly attitude towards themselves by the teacher. In other words, it is a complex social phenomenon that affects many aspects of our daily lives, including higher education. 
At first glance, humor is not an integral part of teaching foreign languages at non-linguistic faculties. Moreover, practice shows that some teachers are not ready to use humor in the classroom for the following reasons: a) they consider humor a «risky» way in communication with students; b) they are often afraid to look ridiculous. They forget that a sense of humor is a trait that is inherent in the human psyche and is one of the components of his or her emotional development [2].

According to the numerous research studies and our teaching experience and observations, humor helps to learn in two ways: directly through the emotional sphere and stimulating the process of cognition and indirectly by means of creating a more welcoming atmosphere, which in turn has a positive impact on the success of knowledge acquisition. From the point of view of language education, both of these factors are important to determine the expediency of using humor in teaching.

Involving the emotional component in the learning process is an essential aspect of the «humanistic approach». At the end of the last century, many studies, especially abroad, emphasized the important and indisputable role of this approach in foreign language teaching, which considers students not only as subjects learning a foreign language, but as psychologically complex individuals in socio-cultural contexts $[6 ; 13]$.

A purposeful impact on the student emotional sphere leads to increasing motivation in language learning because the emotion function is to bring the subject to the real source of those emotions. Emotions indicate the individual sense of events in a student's life. At the same time emotions reflect the significance of the subject's activity content (the assessment function) and establish it for the appropriate work (inducement function) [4, c.304-305].

Modern psychology and pedagogy pay much attention to emotional processes in the mechanisms of mental activity. They are believed to accompany mental processes, activate or inhibit their development, as well as to be the foundation of active functioning in perception, understanding, comprehension, attention and memory. The student's learning activities generate a wide range of emotional experiences. Positive emotions are known to tone the brain, increase the productivity of cognitive processes and promote a creative approach to solving various problems, while negative emotions suppress the brain. The positive emotion of joy that accompanies humor replaces feelings of anxiety, depression, or anger. That allows a person to think deeper and creatively solve problems [7].
Moreover, there is medical evidence that laughter, which usually accompanies humor, does cause profound but not a stressful impact on the whole body, which leads to muscle relaxation and relieves tension provoked by stress and negative emotions [1]. Thus, humor can be seen as an important mechanism for regulating emotions, which can help strengthen students' mental health, especially in the conditions of unprecedented quarantine associated with the COVID-19, which has led to the increased emotional tension in society.

Emotional stimulation facilitates both stability and speed of memorization of educational material as the emotional memory trails are generally formed from the first presentation [4, c.304]. We consider both of these factors important to determine the expediency of the use of humor in foreign language teaching. As humor creates a powerful effect on a person's emotional perception, it is helpful to retain information. It is an important indicator of emotional memory and, therefore, it is a way to increase motivation to learn a foreign language. Emotional disturbance activates important brain's subcortical centers. It tones up the cortex of the cerebral hemispheres and enhances their functional capacity.

It has been recognized that humor has a powerful effect on mental activity and consequently, improving the capacity of involuntary memorization, causes a kind of reflexive orientation to novelty [5].

Conventionally, humor used in our everyday life can be divided into three categories [3]. According to our teaching experience all these three categories function successfully in class:

1) Pre-prepared humorous materials (anecdotes, stories) or so called preserved jokes. Pre-prepared humorous texts are used by foreign language teachers to practice various aspects of the language: phonetics, vocabulary, grammar, listening, etc. The studies show that the use of humor in even test tasks is perceived by most students quite well, provided that the humor is positive and understandable [9].

2) Spontaneous purposeful conversational humor, which is used in the communication process and can be verbal and nonverbal. This type of humor includes anecdotes, funny stories, puns, irony, etc. [11], which are used for emotional relaxation in the audience.

3) Unfocused, or random humor in turn is divided into physical and linguistic types [10]. As a rule, casual humor is the result of a statement or action that should not have been funny from the beginning. Random humor involves cases of misspelling, use and pronunciation of words, accidental permutation of sounds, or «spoonerism». 
In the process of teaching foreign languages, lecturers and students encounter similar cases of humor almost every day, and as a result it can certainly draw attention to particular linguistic aspects. It is important to note that the information presented in a humorous manner is better remembered than information given in a serious way. Thus, such information facilitates cognitive processing, helping to store it in longterm memory [12].

Let us focus on some examples of using humor in class at non-linguistic faculties. For instance, humor can help to acquire new words and word combinations as well as learn new grammar rules. Teachers must have anecdotes at their disposal to illustrate the educational material of various aspects: vocabulary, grammar, phonetics and listening. In vocabulary teaching the jokes may be based mainly on polysemy or homonymy an emphasizing the importance of learning words in English, e.g.

1) A: "I saw a man-eating shark at the aquarium."

B: "That's nothing. I saw a man eating herring at the supermarket."

2) A thief who stole a calendar got twelve months.

3) The dead batteries were given out free of charge.

For better acquisition of Grammar we can suggest the following jokes:

1) Double negatives are a big No-No.

2) Teacher: "Name two pronouns."

Student: "Who, me?"

Using humor, students begin to understand structural and semantic differences between two different languages, state which types of humor fit the speech context.

Practicing jokes, students not only master the material they learn, but are also fascinated by their content that encourages communication. So, students of technical specialties can be interested in various funny stories or anecdotes on professional subjects. Students are fond of jokes with special terms: An electron and a positron go into a bar. Positron: "You are round." Electron: "Are you sure?" Positron: "I'm positive!"

There may be humor-evoking phonetic phenomena involving pronunciation or confusing words. The humor effect is often based on dialect (regional) or peculiar individual pronunciation.

1) A Chinese and a foreigner were competing in a martial art contest and the foreigner won. The Chinese contestant said to his master: "He beat me in the game", but he pronounced the short vowel [i] instead of the long one [i:], that is he said "He bit me in the game." instead of "He beat me in the game." The master criticized that a foreigner: "It is not right to bite others in the contest", which made that foreigner feel pretty wronged.

2) Once a foreign student who was learning in America asked his teacher for a leave to see the doctor. He said: "I'm going to the hospital today". Because of his bad pronunciation, he confused the [ae] and [ie]. In fact, he said: "I'm going to the hospital to die" instead of "I'm going to the hospital today", which sounded scary.

Humor reduces student anxiety and helps to acquire practical skills in using a foreign language, enhances motivation to master the language [14]. For this reason we highly recommend to begin a lesson with a short story or a joke to stimulate students and encourage them to understand further material better.

Humor is an express method of psychological relaxation in class. When experienced teachers see that their students are tired, they can offer them to read humorous entertaining texts or share original jokes and recall some witty episodes. In this case, laughter serves as an unusual stimulus causing their involuntary reaction and is an excellent stress-relief method. A teacher can pick up humorous pictures or photos for specific grammar material or vocabulary practice, and ask students to suggest their comments which will be good for the material assimilation.

A shared perception imposes a certain imprint on the process of understanding due to the influence of the people in class. Laughing together at a joke, both a lecturer and students are likely to form a group with a team spirit of great impulsive power and dynamism. It has a strong effect on behavior as a whole. That gives rise to a solidarity effect which encourages the activity of each student in the group.

Thus humor is one of the most effective ways to influence the audience emotionally, it helps to maintain a lively interest and attention, and create favorable emotional and moral environment at the lesson. Laughter in class is like an infection; the comic effect can be particularly powerful. We strongly believe that laughter is a way to unite people.

Nevertheless, in spite of the fact that humor can play an important role in the process of teaching, we should use it carefully in communication with students.

According to the style, humor can be divided into four types: two relatively healthy, or adaptive affiliative and self-affirming, and two relatively unhealthy, or potentially harmful - aggressive and 
self-deprecating [3]. Most education experts recommend teachers to avoid using aggressive forms of humor. The use of such humor is often associated with less positive assessments of a teacher by students, which in turn can lead to their demotivation.

Therefore teachers should bear in mind that their jokes must not be offensive. "High-risk' humor must be avoided and it is advisable to focus on the 'low-risk' patterns [15]. The jokes must not deal with race, gender, religion and anything that can touch students' feelings to prevent an adverse reaction. We consider that there are safer applications, e.g. telling anecdotes or stories from one's personal life experience. The teacher's ability to laugh at themselves is positively appreciated by students.

It should be noted that humor can play an important role in the process of moral education. They say that mockery penetrates even through the shell of a turtle [3]. Our many years of experience shows that humorous remarks concerning the student's behavior, both in the classroom and outside it, may be quite appropriate and effective. But we should keep in mind the above mentioned requirements.

Discussion and conclusions. Teaching in higher education has long been seen as a process that first of all requires teachers to assess the content of the subject, and find the ways and methods to preset it properly. In general, earlier teachers did not have to think about their interactions with students, both in the classroom and outside it. However, numerous studies and experience show that teaching should include the content of the subject being taught, the search for effective teaching methods and the formation and development of the relationship between a teacher and a student. Teachers must skillfully balance in these two planes in order to effectively facilitate the process of information assimilation.

The teacher's humorous attitude seems to be an essential factor as it addresses the possible complexities and fears that some students of non-linguistic schools have created through a poor foreign language learning experience. Thus, we see humor as a practical tool to establish the right classroom atmosphere and achieve the desired learning goals. The teacher's remarks made in the form of a joke which do not cause offense and are better remembered and even serious conflicts in the team can be easily resolved as a rule.

We must take into account the fact that modern level of foreign language acquisition is characterized by high intensity (students have to revise or learn a great deal of material within a short period of time) and often requires from students an enormous concentration of attention, exertion of strength, and endurance. According to psychologists, educators and doctors, a foreign language is one of the most difficult subjects in the curriculum, which leads to fatigue, overwork and decreased active attention in class. Thus there is a need in health-saving techniques to prevent both negative effects and stress-forming factors. Stress relief in the classroom and the provision of a healthier approach to training is essential. Stress relief can be considered as an effective learning method that contributes to positive emotions and eliminates fatigue and stress, stimulates interest to the subject. This means of relaxation also enables students to understand foreign speakers better, develop correct pronunciation, and master grammatical norms of a foreign language successfully.

Experience has shown that humor is also a powerful tool to overcome the psychological barrier, provide interest to foreign language studies. It creates favorable emotional climate at the lesson which fosters the processes of concentration, memory, thought and creativity. Humor enhances learning motivation as it provides a feeling of joy and satisfaction.

Therefore, in spite of being restricted by time frames of a language course in a higher education institution teachers should pay more attention to using humor in class in order to improve students' acquisition of foreign languages.

\section{СПИСОК ВИКОРИСТАНИХ ДЖЕРЕЛ ТА ЛІТЕРАТУРИ:}

1. Головаха Е. И. Психология человеческого взаимопонимания. $\quad$ К. : Издательство политической литературы Украины, 1989. 190 с.

2. Лук А. Н. Эмоции и личность. М. : Издательство «Знание», 1982.175 с.

3. Мартин Р. Психология юмора / пер. з англ. Санкт-Петербург : Питер, 2009. 478 с.

4. Харенко В.М. Эмоциональные средства регулирования межличностных отношений. Методика интенсивного обучения иностранным языкам. К. : Вищ. шк., 1988. С. 304-320

5. Шерковин Ю. А. Психологические проблемы массовых информационных процессов. М. : Мысль, 1973. 215 c.

6. Atkinson D. Humanistic approaches in the adult classroom: an effective reaction. ELT Journal, 1989. Vol. $43 / 4$. P. 268-273. 
7. Fredrickson B. L. The role of positive emotions in positive psychology. American Psychologist, 2001. Vol. 55 (3). P. 218-226.

8. Lefcourt H. M. Humor: The psychology of living buoyantly. New York : Kluwer Academic, 2001.211 p.

9. McMorris R. Humour in educational testing: A review and discussion. Applied Measurement in Education, 1997. Vol. 10 (3). P. 269-297.

10. Nilsen A. P. Encyclopedia of 20th-century American humour. Phoenix AZ: Oryx Press, 2000.

11. Norrick N. R. Issues in conversational joking. Journal of pragmatics, 2003. Vol. 55(9). P. 1333-1359.

12. Oppliger P. A. Humour and learning: Communications and Emotions. Mahwah, NJ: Lawrence Erlbaum Associates, 2003. P. 255-273.

13. Stevick E. Humanism In Language Teaching. Oxford: Oxford University Press, 1990.

14. Wagner M. Urios-Aparisi E.The use of humor in the foreign language classroom: Funny and effective? Humor. 2011. Vol. 24. № 4. P. 399-434

15. Brenes Reyes, J. R. (2014) Make 'em Laugh: Using Humour To Promote Learning in Language and Literature Classrooms. Teaching Innovation Projects, 4(2). URL: https://ojs.lib.uwo.ca/index.php/tips/article/view/3663

\section{REFERENCES:}

1. Golovaha E. (1989). Psihologiya chelovecheskogo vzaimoponimaniya [The psychology of human mutual understanding]. Kyiv, Ukraine: Izdatel'stvo politicheskoj literatury Ukrainy. (in Russian)

2. Luk A. (1982). Emocii i lichnost' [Emotions and personality]. Moscow, Russia : Izdatel'stvo «Znanie». (in Russian)

3. Martin R. (2009). Psihologiya yumora [The psychology of humor] (Trans. from English). Saint-Petersburg, Russia : Piter. (in Russian)

4. Harenko V. (1988). Emocional'nye sredstva regulirovaniya mezhlichnostnyh otnoshenij [Emotional means of regulating interpersonal relationships]. Metodika intensivnogo obucheniya inostrannym yazykam. (pp. 304320). Kyiv, Ukraine: Vishcha shkola. (in Russian)

5. Sherkovin Y. (1973). Psihologicheskie problemy massovyh informacionnyh processov. Moscow, Russia : Mysl'. (in Russian)

6. Atkinson, D. (1989). Humanistic approaches in the adult classroom: an effective reaction. ELT Journal, Vol. 43/4, 268-273. (in English)

7. Fredrickson, B. L. (2001). The role of positive emotions in positive psychology. American Psychologist, Vol. 55 (3), 218-226. (in English)

8. Lefcourt H. M. (2001). Humor: The psychology of living buoyantly. New York : Kluwer Academic. (in English)

9. McMorris R. (1997). Humour in educational testing: A review and discussion. Applied Measurement in Education, Vol. 10 (3), 269-297. (in English)

10. Nilsen A. P. (2000). Encyclopedia of 20th-century American humour. Phoenix AZ: Oryx Press, (in English)

11. Norrick N. R. (2003). Issues in conversational joking. Journal of pragmatics, Vol. 55(9), 1333-1359. (in English)

12. Oppliger P. A. (2003). Humour and learning: Communications and Emotions. Mahwah, NJ: Lawrence Erlbaum Associates. (in English)

13. Stevick E. (1990). Humanism In Language Teaching. Oxford: Oxford University Press. (in English)

14. Wagner M. Urios-Aparisi E. (2011). The use of humor in the foreign language classroom: Funny and effective? Humor. Vol. 24(4). 399-434

15. Brenes Reyes, J. R. (2014) Make 'em Laugh: Using Humour To Promote Learning in Language and Literature Classrooms. Teaching Innovation Projects, 4(2). (in English) URL: https://ojs.lib.uwo.ca/index.php/tips/article/ view/3663 